\title{
Hegemoni Ideologi dalam Cerpen "Surga untuk Lelaki yang Tertipu" Karya Adam Yudhistira (Kajian Hegemoni Gramsci)
}

\author{
Fajrul Falah \\ Fakultas Ilmu Budaya, Universitas Diponegoro \\ fajrul.falah@live.undip.ac.id
}

\begin{abstract}
The background of this research is there is an indication that the short story was created not just accentuate the beauty aspects of language and narration. However, the language in the meaningful short stories and the author's ideological message through imaginary characters constructed. The purpose of this study is to reveal hegemony and ideology that contains short stories "Surga untuk Lelaki yang Tertipu" by Adam Yudhistira. The research approach used in the realm of sociology of literature, with the study of Gramsci hegemony. The research method used is descriptive qualitative. Research data in the form of language; words, phrases, sentences in the short story related ones are described and interpreted with the Gramsci hegemony approach. The results of the study show the relationship between the teacher's figure and Santo like a patron-client. The teacher has a higher status (superior) and the power to rule Santo (inferior). The ideological hegemony was carried out by the teacher's figure towards Santo went well. Because it has and is bound by the same beliefs. The orientation of the two figures is the same, namely heaven. The ideology instilled by the teacher has a significant influence on the Santo, so he wants to take action that sacrifices the lives of others and himself. The act which was originally believed to be true by Santo, but regretted in the end.
\end{abstract}

Keywords: Hegemony, ideology, teacher, student, heaven.

\section{Intisari}

Latar belakang penelitian ini adalah adanya indikasi bahwa cerpen diciptakan tidak sekadar menonjolkan aspek keindahan bahasa dan narasi. Akan tetapi, bahasa dalam cerpen sarat makna dan pesan ideologis pengarang melalui tokoh-tokoh imajiner yang dikontruksikannya. Tujuan penelitian ini untuk mengungkapkan hegemoni dan ideologi yang terdapat cerpen "Surga untuk Lelaki yang Tertipu" karya Adam Yudhistira. Pendekatan penelitian yang digunakan masuk ranah sosiologi sastra, dengan kajian hegemoni Gramsci. Adapun metode penelitian yang digunakan yaitu deskriptif kualitatif. Data-data penelitian berupa bahasa; kata, frasa, kalimat dalam cerpen SULYT yang terkait dideskripsikan dan diinterpretasikan dengan pendekatan hegemoni Gramsci. Hasil penelitian menunjukkan relasi antara tokoh sang guru dengan Santo seperti patron-klien. Sang guru memiliki status lebih tinggi (superior) dan kuasa memerintahkan Santo (inferior). Hegemoni ideologi yang dilakukan tokoh sang guru terhadap Santo berjalan baik. Hal itu karena keduanya memiliki dan diikat keyakinan yang sama. Orientasi kedua tokoh tersebut pun sama, yaitu surga. Ideologi yang ditanamkan sang guru memiliki pengaruh yang signifikan terhadap Santo, sehingga ia mau melakukan tindakan yang mengorbankan nyawa orang lain dan dirinya. Tindakan yang awalnya diyakini kebenarannya, namun disesali pada akhirnya.

Kata Kunci: Hegemoni, ideologi, guru, murid, surga. 


\section{Pendahuluan}

Tiap-tiap individu cenderung memiliki dan menganut paham sesuai keyakinan masing-masing. Keyakinan tersebut kemudian dianggap benar bagi penganut atau pengikutnya. Paham dan keyakinan yang dimiliki individu tersebut, akan nampak dalam perkataan dan tindakan. Sebagian individu pengikut paham mengimplementasikan dalam perbuatan untuk dirinya sendiri, sebagian yang lain menyebarluaskan paham tersebut. Paham tiap individu bisa diproduksi, didistribusi, dan konsumsi melalui dialog, pembicaraan, dan arena publik. Ada motif dan tujuan individu menyampaikan pahamnya di arena publik di antaranya mengajak, mempengaruhi, bahkan memerintah. Realitas demikian tidak hanya terjadi pada dunia empirik, melainkan juga terjadi dan dinarasikan melalui fiksi, khususnya cerpen.

Cerpen atau fiksi merupakan karya imajinatif yang dikontruksikan sedemikian rupa oleh pengarang. Sekalipun cerpen adalah fiksi, dunia dan narasi dalam cerpen diindikasikan mengacu pada realitas masyarakat pengarang. Cerpen tidak berdiri bebas makna atau netral, ada pemikiran, campur tangan, dan refleksi pengarang terhadap realitas yang diacu. Ada motif dan tujuan pengarang yang ingin disampaikan kepada pembaca. Motif pengarang dalam cerpen dilatarbelakangi beberapa faktor, di antaranya lingkungan, pendidikan, ekonomi, dan aktivitas sosial. Kegiatan sosial pengarang memiliki relevansi dengan hasil karyanya. Ada unsur intrinsik dalam cerpen seperti tokoh, sudut pandang, latar, dan alur yang diciptakan secara imajinatif. Salah satu cerpen yang diindikasikan sarat muatan memuat motif dan makna adalah "Surga untuk Lelaki yang Tertipu" karya Adam Yudhistira (Falah, 2018).

Cerita pendek (cerpen) "Surga untuk Lelaki yang Tertipu" (selanjutnya disingkat SULYT) yang dimuat di harian Haluan sarat makna dan terdapat muatan ideologi-ideologi yang direprensentasikan melalui tokoh-tokohnya. Ideologi tokoh dalam cerpen tersebut relatif nampak, baik secara eksplisit, maupun implisit, sekalipun cerpen dari sisi muatan konflik dan jumlah halaman (narasi) relatif singkat. Cerpen karya Adam Yudhistira yang terbit pada tersebut, seperti memotret sebagian realitas dan permasalahan yang terjadi (di Indonesia), yang dikemas sedemikian rupa oleh pengarang. Persoalan dan potret yang terdapat dalam cerpen tersebut adalah ideologi atau paham keagamaan.

Paham yang terdapat dalam cerpen, dikontruksikan oleh tokoh imajiner seperti guru dan lak-laki tua. Ada tokoh yang memproduksi dan mendistribusi, ada pula tokoh yang mengkonsumsinya (melaksanakan). Tiap-tiap tokoh memiliki dan menjalankan peran sesuai dengan tugasnya masing-masing. Mengapa dalam cerpen tersebut, paham atau ideologi bisa 
disebarkan dengan baik, kemudian dijalankan pula oleh tokoh yang menerimanya? Mengapa pula tokoh yang menerima (mengkonsumsi) ideologi tersebut menjalankan tindakan-tindakan yang oleh tokoh lain dianggapnya sebagai perilaku tidak baik bahkan ekstream? Bagaimana motivasi dan motif yang dimiliki tokoh yang menjalankan ideologi yang diyakininya serta tindakan yang dilakukan?

Cerpen ini menarik diteliti selain karena argumentasi-argumentasi dan pertanyaanpertanyaan yang diuraikan dan diajukan (konflik paham keagamaan), cerpen ini juga terbit relatif baru, yakni 3 Februari 2019. Selain itu, cerpen ini belum pernah diteliti, sepanjang yang penulis ketahui berdasarkan pencarian di internet dan google dengan memasukkan kata kunci "cerpen Surga untuk Lelaki yang Tertipu". Jurnal online terkini yang terindeks doaj.org dan memuat penelitian terhadap cerpen tersebut dengan pendekatan hegemoni ideologi pun belum ditemukan. Penelitian-penelitan yang terkait dengan hegemoni dan ideologi di antaranya (1) Fajrul Falah menggunakan objek formal ideologi dan kelas sosial pengarang untuk mengkaji novel terjemahan Matinya Sang Penguasa (MSP) karya Nawal el Sadawi. Penelitian ini difokuskan pada kajian sastra Marxis. Penelitian ini bertujuan mengungkapkan masalah aspek sosial seperti, relasi novel dengan masyarakat, ideologi, dan srtuktur kelas sosial yang terdapat dalam novel MSP. Hasil penelitian menunjukkan pengarang memposisikan ideloginya dalam novel yang berpihak pada kelas bawah (subordinat). Tokoh utama kelas subordinat, selain memperjuangkan hak-hak yang seharusnya dimilikinya, juga melawan kelas atas (penguasa) dan berakhir dengan kemenangan (Falah, 2017). Penelitian lain (2) Falah memakai objek formal hegemoni ideologi pada novel Ayat-Ayat Cinta Karya Habiburrahman el Shirazy. Fokus penelitian ini menggunakan kajian hegemoni Gramsci. Tujuan penelitian ini untuk mengungkapkan ideologi dan hegemoni yang terdapat dalam novel. Metode penelitian yang dipakai, yaitu deksriptif analitik. Hasil penelitian ini menunjukkan tokoh utama Fahri dalam novel memiliki atribut positif seperti taat, sederhana, cerdas, dan baik hati. Atribut positif tersebut mampu menghegemoni tokoh-tokoh lainnya dalam novel (Falah, 2018). Penelitian terkait ideologi dilakukan oleh (3) Hafizh, dkk (2016) mengkaji novel-novel Jacqueline Woodson dengan mengidentifikasi ideologi dan pola relasinya. Tujuan penelitian ini adalah identifikasi ideologi perbedaan ras, pola relasi, terhadap sastra kulit hitam Amerika dengan pendekatan hegemoni dan postkolonialisme. Hasil penelitian ini ideologi yang terdapat pada novel tersebut, yaitu rasisme, kapitalisme, dan liberalisme. Penelitian-penelitan tersebut menggunakan perspektif hegemoni dan ideologi dengan objek material berbeda. Penulis pada penelitian ini menggunakan objek material cerpen "Surga untuk Lelaki yang Tertipu" karya 
Adam Yudhistira. Penelitian ini bertujuan mengungkapkan hegemoni dan ideologi yang diperankan melalui tokoh-tokoh dalam cerpen .

Hegemoni dapat diartikan sebagai bentuk kekuasaan (menguasai) satu kelas sosial terhadap kelas sosial lainnya. Kelas sosial bisa bersifat komunal ataupun individual. Kekuasaan dengan cara hegemoni, tidak didapatkan melalui kekerasan atau penindasan, tetapi dengan cara konsensus atau persetujuan secara damai. Konsensus tersebut dilaksanakan melalui kepemimpinan politis dan ideologis. Dengan kata lain, kelompok atau indivisu kelas sosial menghegemoni kelas sosial lainnya melalui cara menyebarkan ideologi (Lihat Gramsci, 1971:57; Simon, 2001:21). Ideologi merupakan sekumpulan ide yang oleh kelompok dominan bisa dipaksakan kepada kelompok subordinat. Oleh kelompok dominan, ideologi diproduksi, dikontruksi, dan distribusi melalui cara berpikir, bertindak, dan memahami hubungannya dengan masyarakat. Individu dari perspektif kebudayaan, tidak dipandang sebagai subjek yang netral, tetapi subjek hasil kontruksi sosial masyarakat (lihat Althusser melalui Fiske, 1996:117-118).

Ideologi dalam hal ini, disebarkan tidak hanya secara kolektif, melainkan juga bisa secara individual. Ada tokoh-tokoh atau pihak yang memiliki peran dan otoritas untuk menyebarkan ideologinya kepada kalangan tertentu. Keberhasilan pihak dan otoritas tersebut, bergantung kepada pihak sasaran. Apakah mereka atau sasaran menjalankan ideologi yang diterima atau justru menolaknya. Melalui ideologi, individu bisa melakukan tindakan-tindakan sesuai dengan keyakinannya, bahkan sekalipun tindakan tersebut dianggap ekstrem oleh sebagian kalangan yang menganut ideologi berbeda. Ideologi berfungsi untuk mengikat kelas sosial yang kontra atau antagonis, menjadi harmonis (Lihat Faruk 2010: 135-136; Kurniawan, 2012: 74; Fajrul, 2018: 353).

\section{Metode Penelitian}

Metode penelitian sastra pada umumnya berawal dari perspektif kajian yang digunakan sebagai langkah kerja penelitian. Perspektif kajian dalam penelitian ini adalah hegemoni Gramsci. Adapun objek formalnya adalah hegemoni dan ideologi. Sumber data dan objek material penelitian ini adalah cerpen "SULYT". Analisis terhadap cerpen "SUYLT" dilakukan dengan dua tahapan: (1) mengidentifikasi bentuk ideologi tokoh yang terdapat dalam cerpen, (2) mengungkapkan bentuk hegemoni yang dilakukan tokoh dalam cerpen "SUYLT". Analisis tahap satu (1) dilakukan dengan cara mencermati bahasa, kata, frasa, kalimat yang terdapat dalam narasi cerpen secara menyeluruh yang masuk ciri atau kategori ideologi. Setelah identifikasi ideologi ditemukan, kemudian analisis tahap dua (2) mengidentifikasi bentuk-bentuk yang 
masuk ciri hegemoni dalam teks cerpen. Hasil analisis terhadap cerpen tersebut, disajikan secara deskriptif kualitatif.

\section{Hasil dan Pembahasan}

\section{Struktur Kelas Sosial}

Sebelum masuk ke analisis ideologi dan hegemoni, diuraikan dahulu struktur kelas sosial yang terdapat dalam cerpen "SULYT". Uraian struktur kelas sosial untuk memudahkan pemahaman dan memperjelas analisis. Ada dua kelas sosial yang relatif dominan terdapat dalam cerpen "SULYT", yakni kelas dominan dan subordinat. Kelas dominan direpresentasikan oleh tokoh yang berperan sebagai guru dengan gender laki-laki tua, sedangkan kelas subordinat direpresentasikan oleh tokoh Santo. Pembagian kelas sosial berdasarkan status dan peran tokoh masing-masing. Sebagai guru dan kelas dominan, ia bertugas mengajarkan dan menyebarkan gagasan atau ideologinya kepada orang lain (murid). Tokoh Santo, kelas subordinat, menerima gagasan-gagasan yang disampaikan oleh sang guru. Tokoh guru memiliki posisi strategis karena punya otoritas dan bisa mengendalikan, "Sejak ia berguru kepada lelaki tua itu, Santo menanamkan nasihat itu ke dadanya (SULYT, 2019:1)". Santo tidak mempunyai posisi tawar yang tinggi karena ia justru pihak yang dikendalikan (objek dan penerima). Santo cenderung menerima apa-apa yang disampaikan oleh sang guru.

Sebagai objek, tokoh Santo dalam cerpen dideskripsikan dan dapat diinterpretasikan sebagai murid yang penurut dan patuh terhadap guru. Gagasan-gagasan atau ideologi yang disampaikan sang guru kepada Santo, dan dianggap baik oleh keduanya, diterima dan diwujudkan melalui tindakan. Tidak ada diskusi kritis, apalagi mempertanyakan gagasan yang disampaikan guru. Dalam bahasa kalangan murid (Santo), dikenal kalimat "guru harus digugu dan ditiru" atau istilah "jika ingin ilmu bermanfaat, maka taati dan muliakan guru". Istilah-istilah yang membuat guru dalam posisi dominan tersebut, dipegang betul oleh Santo, sehingga ia menghormati sang guru. Proses distribusi ideologi (transfer of knowledge) dan relasi antara sang guru (laki-laki tua) dengan Santo, tidak dalam ranah pendidikan formal; ada ruang kelas, terjadwal, dan sebagainya, tetapi dalam dialog yang bersifat informal.

\section{Ideologi Keagamaan}

Cerpen "SULYT" terdapat muatan-muatan ideologi keagamaan. Muatan ideologi tersebut direpresentasikan melalui tokoh laki-laki tua (sang guru) dan Santo (murid). Tidak dijelaskan secara eksplisit dan disinggung secara implisit, tokoh-tokoh lain dalam cerpen tersebut. Tokoh 
dalam cerpen tersebut relatif terbatas. Dua tokoh dalam cerpen berdialog terkait agama. Dimaknai ideologi keagamaan karena tema dan isu utama yang terdapat dalam cerpen tersebut, terkait dengan agama (surga dan akhirat). Tidak disebutkan secara langsung agama atau kepercayaan mana yang dimaksud, "janji surga bagi Santo ibarat secawan anggur yang manis. Semakin diminum, semakin memabukkan. Sedangkan agama, ibarat laut kenikmatan yang maha luas. Semakin jauh ia menyelam, semakin dalam ia tenggelam''(SULYT,2019:1). Tokoh sang guru mendistribusikan ideologi yang dipercayainya kepada tokoh Santo. Tokoh sang guru dalam hal ini berposisi sebagai subjek (user) dan Santo sebagai objek (customer).

Ideologi keagamaan dalam cerpen "SULYT” ini juga dimaknai sebagai ajaran-ajaran yang berisi konsep (pedoman) hidup, etika, tindakan benar atau salah. Agama dalam hal ini, diyakini kebenarannya, bagi penganutnya masing-masing. Kebenaran terhadap agama yang dianutnya dalam cerpen direpresentasikan oleh tokoh Santo. Santo meyakini secara sadar bahwa agama yang dianutnya adalah benar, "Mata belianya memandang agama adalah kebenaran mutlak yang harus dibela"(SULYT,2019: 1). Santo tidak hanya meyakini agamanya yang dianggap benar, tetapi melakukan apa yang menjadi perintah apa yang diyakininya. Keyakinan Santo terhadap kebenaran agamanya, bahkan sampai menganggap agama lain salah. Ideologi dalam cerpen ini, berfungsi memberikan pengaruh terhadap individu (Santo). Keyakinan yang berpengaruh terhadap tindakan Santo.

Pengaruh dan distribusi ideologi bermacam-macam, bisa dari tataran awal; dari pengetahuan diajarkan menjadi sekadar tahu. Kemudian tataran menengah, dari tahu atau pengetahuan menjadi keyakinan, dan tataran atas dari keyakinan menjadi tindakan. Tahap atau tataran awal, pengetahuan yang diajarkan kepada Santo. Santo dibekali oleh guru melalui kitabkitab yang menarasikan kepahlawanan orang-orang terdahulu yang perlu dicontoh. Sebagai tokoh yang awam terkait keagamaan, ajaran tersebut menjadikan Santo tahu. Proses menjadi tahu ini kemudian menjadikan keyakinan, atau tahap menengah. Santo meyakini ajaran-ajaran yang disampaikan sang guru, di antaranya membela agama yang diyakininya dengan harta dan jiwa, agama merupakan kebenaran mutlak. Implikasi

Tokoh Santo dalam cerpen, menjadikan ideologi berfungsi pada tataran akhir atau teratas. Segala pikiran dan tindakan Santo mengacu pada ideologi yang diterima dan diyakini kebenarannya. Ada harapan-harapan baik yang menjadikan Santo mengimplementasikan ideologinya. Janji surga dan kemuliaan adalah sebagian dari dasar Santo melakukan tindakan, terlepas apakah tindakan-tindakan tersebut dinilai baik atau buruk oleh individu atau ideologi lain. Dengan demikian, ideologi keagamaan dalam cerpen "SULYT", tidak hanya bisa 
mempengaruhi individu, melainkan juga menjadikan identitas individu, dalam hal ini tokoh Santo.

Ideologi keagamaan yang menjadi identitas Santo, merupakan refleksi diri dan perilaku, yang berbeda dengan kelompok lain. Hal tersebut terjadi manakala kehidupan dunia Santo semata-mata untuk meraih surga dan kemuliaan. Surga lebih dipentingkan Santo daripada dunia, bahkan dunia cenderung diabaikan. Santo menempuh jalan untuk meraih surga yang dicitacitakan dengan cara bunuh diri dan mengakibatkan banyak korban jiwa, "Pada langkah ke tigapuluh, lelaki itu menekan picu di dadanya dan semuanya menjadi gelap seketika" (SULYT, 2019: 2).

\section{Hegemoni Ideologi}

Proses hegemoni dalam cerpen "SULYT" dilakukan bukan dengan cara kekerasan atau anarkis, tetapi melalui konsensus atau persetujuan. Hegemoni ideologi dalam cerpen tersebut tidak berjalan otomatis atau sendiri, ada tokoh yang memainkan peran bahkan memegang kendali atas pihak yang terhegemoni. Tokoh sang guru dalam cerpen memiliki kendali atas tokoh Santo. Proses hegemoni ideologi kedua tokoh pun berjalan baik dan harmonis. Hal tersebut dikarenakan misi keyakinan keduanya sama, yakni mengejar surga. Santo ingin mencari kemuliaan berupa surga, sementara sang guru menawarkan dan menuntunnya ke jalan meraih surga. Santo sebagai pihak yang terhegemoni lebih bersikap pasif, seperti umumnya murid mendegarkan petuah sang guru dalam proses belajar. Sang guru berperan aktif memberikan nasihat-nasihat dan menunjukkan jalan surga kepada Santo.

Hegemoni ideologi sang guru kepada Santo semakin kuat, hal ini dikarenakan didukung kutipan dan dalil-dalil agama yang oleh keduanya diyakini kebenarannya. Dalil yang dikutip sang guru menunjukkan bahwa hegemoni ideologi dimulai melalui pernyataan. Peryataan sang guru yang harus dilakukan Santo, tetapi tidak untuk dirinya. Kesadaran posisi dan perintah tersebut, tidak membuat Santo mempersoalkan, apalagi membantahnya. Hal itu karena, relasi antara tokoh sang guru dengan Santo seperti patron-klien (patronase). Santo dengan sang guru tidak dalam posisi sederajat (ekuivalen). Dilihat dari status dan kekuasaan menempatkan Santo (klien) pada posisi lebih rendah (inferior), sedangkan sang guru pada posisi superior.

Pola relasi patronase membuat Santo taat mengikuti perintah sang guru, sekalipun sang guru tidak terlibat langsung atau bersama menjalankan tugas dan mewujudkan mimpi Santo, yakni surga. Hal itu tergambar melalui kutipan berikut, "Selamat jalan," kata lelaki tua itu pada Santo. "Kau telah berhasil memenuhi semua syarat yang dibutuhkan. Pergilah dengan hati bulat. 
Doaku selalu menyertaimu." (SULYT, 2019:2). Kutipan tersebut menunjukkan hegemoni ideologi yang diikat melalui hubungan patronase dan keyakinan, memiliki pengaruh yang kuat. Ucapan dan perintah patron (sang guru) dengan mudah diimplementasikan melalui tindakan nyata oleh sang kilen (Santo). Kekuasan hegemonik dan transfer ideologi yang dijalankan sang guru berhasil.

Ideologi tidak hanya memiliki peran sistem hegemoni, melainkan juga mengikat antarkelas atau strata sosial. Hegemoni yang diikat melalui ideologi, semakin kuat sehingga cenderung tidak menimbulkan konflik antarkelas dengan ideologi yang sama. Frasa "selamat jalan" yang diucapkan sang guru kepada murid (Santo), di satu sisi jika dilihat pada ketidaksamaan ideologi, bisa dimaknai perpisahan. Perpisahan yang jika merujuk pada konteks perjuangan Santo yang bertaruh nyawa, bisa dimaknai meninggal. Hal tersebut dikuatkan dengan frasa penutup dari sang guru "semoga berhasil", menunjukkan tidak ada kepastian apa yang dilakukan Santo berhasil. Pemaknaan-pemaknaan tersebut tersamarkan bahkan berbeda yang diterima oleh Santo. Jika dimaknai dalam konteks kesamaan ideologi, frasa "selamat jalan", menunjukkan dukungan penuh sang guru terhadap Santo. Hal itu juga dikuatkan melalui frasa "semoga berhasil" yang mengindikasihan ada harapan positif dari perjuangan yang dilakukan Santo. Jika dilihat dua pemaknaan tersebut, maka makna kedua (kesamaan ideologis) yang lebih relevan bagi Santo.

Ideologi yang mengikat Santo, membuat apa yang diperjuangkannya dianggap benar dan optimis berhasil karena mendapat dukungan langsung dari sang guru, "Ku tunggu kau di pintu surga, surga adalah sebaik-baik tempat kembali" (SULYT, 2019:2 ). Kata surga, mampu menggerakkan diri Santo melalukan tindakan yang bahkan sampai mengancam nyawa orang. Sekalipun dalam hati kecil Santo, terbesit dan tidak membenarkan tindakan tersebut, namun ideologi yang sudah menjadi keyakinannya mampu mengalahkan hati kecilnya. Kenyataan tersebut tergambar, sebagaimana kutipan berikut, "Pemuda itu menyingkirkan pikiran dan pandangan matanya pada kenyataan bahwasanya sebagian dari para pengunjung kafe itu hanyalah anak-anak dan wanita. Pada langkah ke tigapuluh, lelaki itu menekan picu di dadanya dan semuanya menjadi gelap seketika" (SULYT, 2019:2).

Kutipan di atas menunjukkan bahwa tindakan yang dilakukan Santo memakan korban nyawa, termasuk dirinya. Ideologi yang sudah mengikat, mampu membuat seseorang (Santo) melakukan tindakan yang menjadikan nyawa sebagai taruhannya. Harapan surga yang dijanjikan guru setelah ia (Santo) tiada, tidak kunjung datang. Santo mulai ragu dengan tindakannya dan mempertanyakan surga yang dicita-citakannya. "Kau telah tertipu. Kau tak menggunakan akal 
dan pikiranmu. Tidak ada surga untukmu. Tidak akan pernah ada" (SULYT, 2019: 4). Kutipan tersebut menunjukkan, kenyataan tidak sesuai dengan harapan (Santo). Gagasan-gagasan yang diyakini Santo, justru membuatnya susah diakhir hidupnya (sad ending). Menurut ranah kajian hegemoni Gramsci, tindakan Santo tersebut masuk sistem kepercayaan menyeluruh.

\section{Simpulan}

Cerpen "Surga untuk Lelaki yang Tertipu" karya Adam Yudhistira sarat makna dan muatan ideologis. Sekalipun cerpen ini fiksi, tokoh, gambaran, pesan yang terkandung di dalamnya memotret dan merefleksikan fenomena dalam dunia riil. Terdapat mekanisme penyebaran ideologi; produksi, distribusi, dan konsumsi yang diperankan melalui tokoh utama sang guru dan murid (Santo). Tokoh guru memiliki peran pemroduksi sekaligus pendistribusi ideologi, sedangkan Santo lebih pada posisi pengkonsumsi. Relasi kedua tokoh berjalan harmonis tanpa ada konflik karena diikat oleh keyakinan yang sama. Keyakinan keduanya melahirkan misi mendapatkan surga. Hegemoni ideologi yang dilakukan sang guru kepada murid (Santo) pun berjalan baik. Hal itu dikarenakan hubungan kedua tokoh itu seperti patron-klien (patronase). Sang guru ditempatkan pada posisi, kekuasaan, dan status superior, sedangkan Santo inferior (rendah). Posisi superior sang guru inilah yang membuatnya bisa memerintah Santo untuk menggapai surga. Surga yang dicita-citakan Santo, ditempuh dengan cara yang bahkan memakan korban termasuk dirinya. Tindakan yang pada akhirnya diragukan kebenarannya dan disesalkan oleh Santo. Dengan demikian, ideologi memiliki pengaruh yang cukup besar terhadap orang yang menjadi sasaran dan menyakininya. Cerpen "SULYT" menampilkan wacana ideologi yang direpresentasikan melalui tokoh-tokoh imajinernya.

\section{Daftar Pustaka}

Falah, F. (2017) 'Ideologi Pengarang dalam Novel Matinya Sang Penguasa Karya Nawal el Sadawi: Kajian Sastra Marxis', 12(2), pp. 100-107.

Falah, F. (2018) 'Hegemoni Ideologi dalam Novel Ketika Cinta Bertasbih Karya Habiburrahman el Shirazy (Kajian Hegemoni Gramsci)', Nusa: Jurnal Ilmu Bahasa dan Sastra, 13(4), p. 533. doi: 10.14710/nusa.13.4.533-542.

Falah, F. (2018) 'Pertentangan dan Kesadaran Kelas Sosial dalam Cerpen “Tikus Raskin” Karya Kartika Catur Pelita (Kajian Sastra Marxis)’, 487, pp. 487-496.

Faruk. 2010. Pengantar Sosiologi Sastra dari Strukturalisme Genetik sampai Post-Modernisme. Yogyakarta: Pustaka Pelajar.

Fiske, John. 1996. "British Cultural Studies and Television", dalam John Storey (ed). What is Cultural Studies?: A Reader. London: Arnold. 
Gramsci, Antonio. 197. Selections from Prison Notebook, edited and translated by Quentin Hoare and Geoffray N Smith, London: Lawrenceadn Wishart.

Hafizh, dkk. 2016. Identifikasi Ideologi dan Pola Relasinya dalam Novel-Novel Jacqueline Woodson. Jurnal Atavisme Vol. 19. No. 2. Diakses melalui http://atavisme.web.id/index.php/atavisme/article/view/252, pada 21 Februairi 2019, pukul 22.10 WIB.

Kurniawan, Heru. 2012. Sosiologi Sastra: Teori, Metode, dan Aplikasi. Yogyakarta: Graha Ilmu.

Simon, Roger. 2001. Gagasan-gagasan Politik Gramsci. Terj. Kamdani dan Imam Baihaqi. Yogyakarta: Pustaka Pelajar.

Yudhistira, Adam. 2019. "Surga untuk Lelaki yang Tertipu”. Harian Haluan. Diakses melalui, https://lakonhidup.com/2019/02/03/surga-untuk-lelaki-yang-tertipu/, pada 19 Februari 2019 pukul 19.03 WIB. 